\title{
1 Socialism Between Détente and Globalisation
}

\author{
Federico Romero
}

Historians have increasingly connected the demise of Europe's socialist regimes with late twentieth-century global economic transformations. Several interpretations of 1989 focus on the undermining effects globalisation had on the late socialist economies and, more crucially, on its 'ideological erosion' of the regimes' solidity, legitimacy and self-confidence. ${ }^{1}$

After the collapse of the Bretton Woods monetary system and the 1973 oil crisis, growing trade competition and market liberalisation redesigned international commercial and financial flows. Multinational corporations connected by new communication and information technologies reshaped productive and distributive networks. The explosive growth of global finance - with international lending rising more than tenfold between 1970 and 1980 - fuelled these processes and built new dynamics of wealth and power. ${ }^{2}$

With goods and capital moving worldwide in unprecedented amounts and at an increasing pace, the landscape in which socialist economies operated was transformed more quickly and unpredictably than socialist officials could fathom or cope with. Their efforts to make their economies more productive by expanding trade with, and technology transfers from, the West turned sour by the late 1970s, and ever-increasing financial imbalances constrained their options, in a few cases to the point of suffocation. By the 1980s they had fallen victim to 'the kiss of debt', and poor economic performance called into question the very rationale upon which their strategies had been built: 'if socialism was merely aiming at placating consumers just like capitalism, only not as well, was socialism's existence even justified?'3

Of course, economic dynamics were linked to ideological and cultural factors that deepened socialism's predicament, hindering its residual rationale and hollowing out its core meaning. While socialist modernisers were trying to temper the rigidities of planning with limited simulated market mechanisms, the Keynesian consensus was fast unravelling in the West. Rather than the presumed convergence of 'market socialism' and Keynesian mixed economies towards rationally planned industrial societies, the 1970s ushered in a free market ideology that eventually dismantled the societal and economic paradigms underlying post-war recovery. ${ }^{4}$ 
Individual competition rooted in a market concept was hailed as the foundation of freedom and contrasted with the state as the source of authoritarianism. In this starkly binary logic, "freedom of choice" rose from being a consumerist slogan to an overarching paradigm of pervasive influence. ${ }^{5}$ Soon dubbed "neo-liberal", this paradigm of market individualism in a context of deepening global interconnectedness not only sustained a fierce criticism of communism but also struck at the core of any planning and redistributive policy, disabling social-democratic and Keynesian frameworks, which relied primarily on national policy tools. Tighter interdependence and capital mobility forced adjustments at any level - regional and national, between sectors and within firms.

This major systemic transition was deeply upsetting everywhere and the Western economies underwent difficult, often painful changes. However, they adapted better than those of Eastern Europe. After comparable achievements in the two post-war decades, economic performances diverged markedly. Between 1973 and 1989, the planned economies of Eastern Europe grew 0.7\% a year, against $2 \%$ for Western Europe. Per-capita income in socialist economies dropped from $49 \%$ to $37 \%$ of Western European levels. ${ }^{6}$ State socialism proved to be 'a blunt instrument, more suitable for rapid industrialisation ... than for progressing to a sophisticated consumer economy'?

These fast-changing conditions made the national economic strategies analysed in this book far more difficult to implement and ultimately unsuccessful. It was not merely an economic failure to improve productivity and upgrade technology, although this was crucial. The demise of strategies depending on deeper exchanges with the West meant the socialist regimes of central-eastern Europe lost their attempt at overcoming the key long-term dependencies that hampered them and to a large extent defined them.

They were struggling, first, with their historically sedimented condition of "peripheral" economies subordinated to Europe's north-western industrial core. Even though Stalinist industrialisation had transformed their domestic economic agrarian structures, their actual and potential trading relations with the advanced industrialised economies of the West remained disproportionally dependent on exporting primary products and low-tech goods. For Poland, Hungary and Yugoslavia, and even more so for Bulgaria and Romania, catching up with the most advanced economies was a long-term national goal no less than a key imperative of socialist ideology. ${ }^{8}$ Its pursuit might have appeared long and difficult but far from unthinkable in the 1960s and early 1970s, but within a decade it turned out to be an untenable delusion.

Historical "backwardness" was compounded with the relative isolation imposed by the early Cold War partition of Europe in opposite and largely separate camps. Ever since the launch of the Marshall Plan in 1947, Western management of the international economy also aimed to isolate the socialist economies. The institutions, rules and practices of post-war multilateralism ensured they remained fenced in a closed sphere with minimal interchanges with Western capital and advanced technology. No less crucial, of course, was the Stalinist strategy of creating 
an insulated self-blockaded socialist camp - which operated in paradoxical synergy with Western decisions.

Historical scholarship has debunked, or at the very least seriously qualified, the Cold War myth of an impermeable dour socialist autarky. Excluded from the post-war international economy framed by Western multilateralism, the socialist countries strived to build up trade amongst themselves and a planned division of labour through the Council for Mutual Economic Assistance (CMEA). Although this seemingly complemented the bloc's military and ideological cohesion, it neither functioned efficiently for economic integration nor satisfied the participants' key economic ambitions. The Soviet Union gained little economically and soon had to provide its partners with support, while they resisted plans for intra-regional specialisation, strived to maximise their individual shares of Soviet subsidies and usually pursued their own national goals. ${ }^{9}$

This system was not particularly efficient and certainly unsatisfactory, not least for the central-eastern European socialist countries mired in a 'dual dependency' 10 on the region's dominant imperial power and the core economies of the capitalist world, yet it embodied and to a certain extent sustained the post-Stalinist effort to deepen socialism's transnationalism, connect with the world and build networks of global exchange.

Recent studies investigate the multiple deep expanding connections the socialist world built within its own boundaries and with other societies, particularly in post-colonial settings but also in the West. They make a strong case for a far more plural reading of the various internationalist projects and frameworks that not only competed but often overlapped and got intertwined in the complex transformations from the 1960s onwards. ${ }^{11}$ They challenge the teleological view of a single inescapable neo-liberal globalisation and replace it with proper historical questions on the goals, pressures and specific terms under which different states decided to open up their economies. ${ }^{12}$ Above all, they reassess the place and role of socialism in global history, its contribution to a culture of global change in the second half of the twentieth century and its practices to connect with the "third world" in projects of alternative internationalisation. ${ }^{13}$

Of course, assessing socialism's contribution to globalisation, or conceptualising an alternative path to globalisation, is a challenging endeavour, not least because the communists purposely 'wrote themselves out of the story of globalisation' with their language of national independence and antagonistic blocs. ${ }^{14}$ Still, the challenge to global capitalist hegemony inspired socialist views and policies from the mid-1950s onwards, and was sufficiently serious to raise considerable concerns in Western capitals. At least until the mid-1970s, the potential for an emerging compact between socialism and the global South seemed real enough to stoke hopes or fears of an alternative international order..$^{15}$

This did not come to pass. Instead, a compelling market globalisation under Western hegemony came to define the closing decades of the twentieth century. The transition from the former prospect to the latter reality defined the mutable environment in which the socialist economies struggled, illuminating their predicaments. 


\section{Federico Romero}

\section{Socialist transformation or stabilisation?}

The Stalinist model of heavy industrialisation had changed the socialist countries' economies, with intense resource utilisation that fuelled their rapid post-war growth. However, their leaders - and particularly Nikita Khrushchev - looked at Western advanced capitalism as their reference point. The aspiration of catching up with the West oriented their compasses for strategic, ideological and material reasons. It was, of course, a Cold War imperative dictated by the need to sustain the antagonism and possibly surpass and outshine the adversary. Furthermore, it was an ideological tenet rooted in Marxist-Leninist views of class struggle and historical progress. However, by the early 1960s it was also increasingly a thrust grounded in more pragmatic goals and implications.

Under Khrushchev, the Soviet leadership embraced notions of accelerated economic growth premised on a shift towards light industry for increased production of a larger range of consumer goods and on expanded trade within the socialist sphere but also with the new post-colonial nations and the West. Above all, it pinned its hopes on a scientific and technological revolution not only to propel the USSR to the role of global superpower but also to project socialism as an alternative superior form of modernity. This entailed a strong emphasis on technological innovation necessitating not only research but also exchanges between East and West - tasks entrusted to a State Committee of Science and Technology created in 1958. ${ }^{16}$ In 1961, the Communist Party of the USSR published a new programme that associated communism with material abundance and promised socialist consumption policies that betrayed a cultural fascination with Western ideas of societal wellbeing and progress, if not an internalisation of Western superiority. ${ }^{17}$

This shift of emphasis was shared, albeit unevenly, by the other European socialist regimes (but harshly criticised by the Chinese), and there, as in the Soviet Union, it brought both desired transformations and unintended consequences and tensions. Investment priorities were at least partially rearranged. In order to tackle key problems of productivity and incentives, a variety of reform experiments were attempted, usually with 'market mechanisms . . . simulated within the framework of the planned economy without introducing the fundamentals of a market economy'. ${ }^{18}$

However, the reorientation of priorities towards satisfying socio-economic needs, and the introduction of even limited market mechanisms, did not sit smoothly with a planning system that had been created to maximise investment in heavy industry and ensure top-down discipline. Frictions soon emerged both in practical terms, as innovations were stifled and productivity gains seriously limited by the inbuilt strength and inertia of the planning mechanism; and in political terms, as the push for incremental changes raised the spectre of a fundamental reshaping of the socialist model, with the possibility of uncontrolled power struggles and systemic destabilisation. ${ }^{19}$

These tensions played out with different features and timing in the various national contexts, producing multiple threads of Marxist reform thinking and projects that flourished throughout the 1960s. ${ }^{20}$ However, the core issue came to 
an abrupt head in summer 1968 when the Warsaw Pact armies suppressed the Prague Spring, the most ambitious and far-reaching experiment in socialist reform. Driven by the strategic need to preserve the cohesion of the socialist bloc, the Soviet-led intervention made clear, once and for all, that political stability overrode any attempt at reforming the socialist economic model. Therefore, it designed a very narrow perimeter of admissible social and economic change. With reforming or defending socialism now alternative options, radical transformations of the planned economy were ruled out. This had two key consequences. First, socialist reform thinking withered - with its advocates either repressed or withdrawn to the safer sphere of technical advice - and it was eventually eclipsed by criticism centred on civil rights rather than ideas of social and economic transformation. Second, acceptable change was redefined 'exclusively in terms of a gradual improvement of the existing order, as expressed by Leonid Brezhnev's ideology of stabilisation'. ${ }^{21}$

With reform policies and politics forcibly shelved, socialist elites concentrated on strategies for growth that would not engender uncontrolled change and risk instability. Alarmed by popular pressure for economic betterment, particularly evident after the December 1970 strikes in Poland, they came to focus on investment and trade solutions geared to "pacify the workers while securing their own power'. ${ }^{22}$ Public welfare and consumption therefore acquired greater priority, and one of the ways to achieve them came to be seen in increased imports of technology and consumer goods from the West, a strategy shared by the entire bloc (with the exception of Czechoslovakia in the early years of its 'normalisation') and pursued most intensely by the GDR, Hungary and Poland. Socialism would not be reformed but it could be modernised (so the new doctrine predicted) by enhancing its ability to incorporate the technical achievements of the Western economies.

The pursuit of this rationale was facilitated by another transformation that the 1960s had brought to the socialist sphere. The push for accelerated economic growth, technological exchange and increased trade had expanded the role and reach of CMEA. Spurred also by a genuine, albeit apprehensive, interest in the ongoing dynamics of integration among Western economies, the notion that deeper interdependence should be pursued and organised flourished in socialist capitals. CMEA could develop complementarities and strive for deeper integration and specialisation to enhance growth and strengthen the socialist world. At the height of decolonisation, it was also seen as a tool to elaborate a coherent socialist model to offer to some of the newly independent countries of the global South, aiming to shape a larger socialist sphere encompassing both developed and developing countries and affecting the visible growth of global interconnectedness in original alternative ways.

However, initial projects to coordinate national plans and pursue a bloc-wide division of labour were resisted (or openly rejected, in the case of Romania) by the interplay of divergent national ambitions and interests. The intergovernmental nature of CMEA facilitated processes of national identification and limited Moscow's ability to direct and control institutional dynamics, especially at a time when the Sino-Soviet schism made the unity and discipline of the communist 
movement at the party level substantially less solid. As a consequence, diversity rather than homogeneity increased across the Eastern bloc, with each country pushing for competitive advantage, using the bloc's multilateral structures to carve out space for its own trade deals, enhance its national autonomy and pursue key national goals (the GDR and Poland, for instance, thwarted deals with West Germany until their own bilateral issues - recognition and border settlement respectively - had been solved). A similar dynamic also took hold in relations with the global South. Early attempts at coordinated bloc initiatives with strategic relevance were gradually abandoned and replaced with separate national engagements aimed at trade advantages in a logic of national, rather than bloc-wide, economic improvement. ${ }^{23}$

At the beginning of the 1970s, the developmental discourse steeped in antiimperial solidarity remained dominant, but in actual terms it was being superseded by national strategies with a hard-nosed focus on mutual trade benefits. Among these, the supply of raw materials stood out, but equally crucial was the socialist economies' overarching need to gain hard currency via export, in order to sustain their purchases of investment and consumer goods from the West. Rather than an anti-imperial north-south axis, socialist economic strategies were now prioritising an east-west interchange as the key to a more productive, technologically advanced, consumption-oriented socialism.

\section{Opportunities and expectations of détente}

These economic strategies were inextricably intertwined with détente. The two processes were mutually reinforcing, and usually expected - in the East even more widely than in the West - to succeed together. In Warsaw and Budapest, but also in Bucharest and Sofia, the rising tide of East-West détente spelled an unprecedented moment of opportunity and confidence.

The US-Soviet dialogue on strategic arms control, which had brought the 1968 Non-proliferation Treaty and eventually resulted in the 1972 SALT agreement, was meant to diminish the risk of war and stabilise relations between Moscow and Washington but also to buttress their hierarchical control over their respective blocs. However, unintended consequences abounded, as détente opened up a far wider and mutable political space. Within it, several venues of East-West cooperation could now be explored by a variety of protagonists, whose priorities did not always coincide with those of the two hegemons. ${ }^{24}$

Two crucial factors paved the way to a dynamic multi-level multilateral détente between Eastern and Western Europe. Socialist leaders interpreted the armament agreements as a result of Soviet strategic strength. Regulated nuclear parity for them spelled a safer system of mutual deterrence replacing the previous threat inherent in Western superiority and epitomised the rise of socialist world influence. ${ }^{25}$ Even more pivotal, Willy Brandt's Ostpolitik deflated the fear of German "revanchism," inaugurated a language of cooperation that did not threaten socialist stability and indicated the possibility of mutually beneficial exchanges. In particular, his treaties with Moscow and Warsaw (1970) and with the GDR (1972) 
removed the main legal and historical obstacles to cooperation. They designed a new landscape that seemed to consign the Cold War to history while promising a future of peaceful competition between socio-economic systems. ${ }^{26}$

Thus the economic strategies for faster socialist growth based on technological exchanges, credit from the West and an expansion of consumption found their most promising environment in the policies of détente pursued at the diplomatic level. Intensified cooperation would promote trade and partnership deals, thus feeding the ambitious economic goals set in Warsaw or Budapest, while extended exchanges (not only with West Germany, but also with the rest of Western Europe) would in turn provide robust foundations for a durable détente. Socialist leaders saw in this virtuous circle the prospect of self-consolidation with faster economic growth, a possibility for the cautious pursuit of national goals and the best option to 'make detente irreversible'. ${ }^{27}$

These views converged with those of most Western European governments (including the neutral ones), which saw détente not just as an interstate process but rather as a new horizon of cooperative security rooted in growing interdependence among economies, societies and peoples. Increasing trade and exchanges with Eastern Europe could be seen primarily as a political tool, as the US did, with the goal of rewarding and stimulating each government's relative autonomy from Moscow. ${ }^{28}$ However, they could also be imagined as tools for ambitious long-term transformations. This had been one of the original tenets of Ostpolitik and was fast becoming a shared grammar not only within Western European governments and the European Community but also among religious and civic associations, political parties, transnational activists and even business circles. If intensified trade, credit and technological cooperation could go together with increased contacts, ease of travel and tourism, and societal and cultural exchanges, the ensuing interdependence would foster mutual confidence, shared interests and (possibly) an easing of the East-West divide. Confident in their superior economic strength and democratic legitimacy, Western European actors trusted the attractiveness of their social model to gradually open up socialist societies, temper their rigidities and perhaps in the long run erode their regimes' authoritarian nature and hostile postures. ${ }^{29}$

The main overarching venue in which these strategies and expectations converged was the Conference for Security and Cooperation in Europe (CSCE), which in Helsinki in 1975 produced a broad accord on East-West relations, contacts and exchanges. It enshrined the twin pillars of intra-European détente, the double notion that states would respect each other's sovereignty and borders but would also facilitate mutual trade, travel and transnational societal interactions. ${ }^{30}$ This was the high point of détente and was seen in the socialist sphere as the crowning of its effort to obtain international legitimacy and stability. At the same time, it opened up new areas of competition and potential tensions, particularly on human rights, that would eventually challenge the socialist regimes' domestic discipline and control. ${ }^{31}$

Among socialist officials, concerns about capitalist encroachments, dependence on the West's superior economic power and the corrupting effects that consumer 
culture could have on social discipline and cohesion were far from absent. Such fears were outweighed, though, by new expectations of safety, stability and prosperity. These hypothetical risks - including those related to human rights appeared manageable and seemed more than balanced by Helsinki's substantial results and promises. ${ }^{32}$ Stable and durable détente was the key strategic prospect for peace and stability. Moreover, as economic strategies were pivoted on expanded trade and cooperation with the West, multilateral détente offered important opportunities for national improvement and even some degree of autonomy. In the mid-1970s, socialist governments could still look at their prospects and predicaments with considerable confidence, not least because the West was not faring very well as it was mired in its major post-war crisis.

The demise of the Bretton Woods monetary system had brought instability and uncertainty coupled with transatlantic frictions and mutual recriminations. Foreign policy divergences - first on Vietnam, then on the management of détente and finally on the Middle East - intersected with economic issues, opening up a considerable gap between Washington and its European allies. The European Community was openly searching for a foreign policy role of its own and trying to assert its economic power. Socialist leaders resurrected the notion of an impending crisis of capitalism and mused on Western Europe's potential emancipation from US hegemony. There was, of course, an element of wishful thinking in all this, but they were neither alone nor daydreaming, as many in the West also looked with trepidation at the implications of trans-Atlantic frictions and rivalry. ${ }^{33}$

Then the oil crisis added a shocking existential dimension to the sense of impending crisis. The rise in oil prices signalled to Western societies that their long post-war boom was over and that their dominance of the international terms of trade was challenged, by OPEC in a direct way and more broadly by a large coalition of developing countries that demanded a new, more equitable international economic order. ${ }^{34}$

With the ensuing recession, unemployment resurfaced in the West and inflation took off. The post-war winning combination of growth and democratic stability suddenly appeared shaky. Economic policymaking and business plans had to be rearranged in a fractious landscape that exasperated national and trans-Atlantic divergences. Preserving the West's multilateral system required new tools and institutions for the management of interdependence..$^{35}$ As a result of this crisis, a complex multi-level reshaping of the world economy got under way. Under new paradigms of market competition and financial liberalisation, Keynesian demand management was replaced with policies of privatisation, deregulation and fiscal austerity, ushering in the dynamics and concept of globalisation that would eventually triumph after $1989 .{ }^{36}$

At first, though, no one anticipated this deep successful restructuring of Western dominance. The crisis was so multi-dimensional and severe (at least between 1973 and 1976) that it evoked spectres of Western decline. For a short moment, predictions of a crisis of capitalism appeared no more fanciful than expectations of its global resurgence. 
Therefore, socialist leaders saw far more opportunity than risk. The oil crisis raised demand for (and returns on) Soviet oil, coal and other raw materials. Western European corporations were eager to find new export markets. Multinationals were reorganising production networks worldwide. The spectacular rise of Japan's industrial and trading power appeared as an enticing example of catchingup achieved through integration in the international market. Even more crucially, the recycling of OPEC oil revenue provided Western banks with abundant capital for loans that inflation would make cheaper to repay. Thus, socialist planners with a modernising attitude 'saw . . . a unique set of opportunities for upgrading the path of socialist economic development' ${ }^{37}$ It seemed a favourable moment to engage economically with the West.

\section{Systemic inadequacy and external constraints}

National strategies based on imports and credit from the West initially achieved remarkable results. Between 1971 and 1975, economic growth was intense, exceptionally so in Poland and Romania. Consumption rose to unprecedented levels, as it did in the GDR. Exports to OECD countries also grew. Hungary launched many cooperation agreements in light industry, as did Romania and Yugoslavia with several joint ventures.

However, this opening of (relatively) closed economies made the socialist countries vulnerable to the shocks and tensions of a globalising world economy and exposed their planning systems to strains and competitive pressures. In a few years, problems piled up, uncovering serious shortcomings and vulnerabilities, and key indicators became almost unsustainable. The trade deficit of the six central-eastern European countries grew from 1.2 billion US dollars in 1972 to 6.6 billion US dollars in 1978, and their debt to the West from 4.9 billion US dollars in 1971 to 48.5 billion US dollars in 1979 (almost half of which was Poland's). ${ }^{38}$

There were several intertwined root causes of this cycle. As the chapters in this book demonstrate, the elements of flexibility introduced in the system to make it more responsive to international trade were far from sufficient. Even though there were large variations among countries, firms and enterprise associations were usually given more autonomy and foreign trade authority was partially decentralised. However, the inherent inefficiencies of the planning system remained entrenched and they hampered the overall effort for a technological and productivity upgrade. Even the firms more directly affected by new equipment imported from the West and those involved in the export drive to gain hard currency were often held back by bottlenecks and poor quality suppliers. This limited their efficiency gains, their output of new products and their export opportunities. The impact of new technologies and processes was also constrained by the nature of socialist enterprises, which could not restructure - in particular, replace workers with machines - with the rapidity and suppleness of capitalist firms. Additionally, much new investment went to traditional heavy-industry sectors like steel, coal and refineries due to their superior lobbying power entrenched within the party-state apparatus and the prevailing economic and administrative culture in the planning system. In 
broad terms, a planning structure designed for mass production of standardised goods fared poorly when confronted with the needs to become flexible and innovative, to diversify its products and to adapt to the increasing relevance of services. Therefore, even though some productivity gains were achieved - especially in Poland, Hungary and the GDR - systemic inefficiencies reduced the potential impact and expected benefits of the new strategies.

A second set of difficulties concerned export opportunities, which turned out to be less ample than expected. Low-end sectors in which the Eastern European economies could be competitive, like textile and agricultural goods, were often protected in Western markets, and particularly so in the most crucial neighbouring EEC. In the mid-level technology range, industrial products - even the new ones that were being developed with imported Western equipment and licenses - had to compete not only with Western rivals but with the rising prowess of the East Asian industrialising economies, which pursued coherent export drives and were rapidly conquering markets worldwide. As a result, inefficiencies and poor reliability on the domestic side interacted with increasingly competitive dynamics abroad to make socialist exports too often costly, unappealing or simply outperformed by their Western and Asian rivals. Several socialist governments even tried to use international institutions to position themselves as developing economies (in marked contrast with socialism's own self-representation) so as to obtain preferential access to the richer markets, particularly the EEC. In this endeavour, they emulated Yugoslavia's established policy and stance. However, unlike Yugoslavia, they obtained scarce results. ${ }^{39}$ Gaining substantial permanent export shares in the West and the developing economies of the global South proved to be quite difficult. Even though international trade as a proportion of global GDP rose spectacularly throughout the 1970 s, the socialist economies intercepted only a small quota of it. Too small, that is, to balance the growing volume of imports that they had to pay for with hard currency. Thus the productivity gains and welfare improvements that the new economic strategies initially achieved soon ran against increasing external constraints..$^{40}$

The key measure of these growing difficulties - and the noose that would eventually doom the new strategies - was the fast-expanding foreign debt with Western banks and governments. Several factors contributed to its rapid growth. The prediction that rising energy prices would help the socialist economies soon went into reverse. Oil sales brought more revenue to the Soviet Union but a new CMEA price formula - designed to reduce the differential with world prices - meant that energy costs for the central-eastern European countries started to rise from 1975. The prices of other raw materials and intermediate goods that sustained the new productions also rose. Thus, foreign expenditure grew faster than revenue from exports. Moreover, no small amount of foreign credit was used to finance consumption (in accordance with the new policy's welfare rationale) rather than productivity-enhancing investment.

Rising foreign debt was initially seen as temporary, and therefore inherently manageable. As exports were expected to grow and bring hard currency, the rationale for a debt-fuelled investment spurt appeared sound. However, the 
mechanism never came close to its anticipated balance. Even when good, export performances were not sufficient to offset the growing trade and finance imbalance. Several new investments turned out to require constant additional imports of raw and intermediate materials, thus further stretching debt creation into the future. The devolution of authority reduced the planning system's internal consistency and empowered regional, sectoral and company managers to lobby for their own interests, over-invest and increase the debt's growth. There were other domestic imbalances. In the most extreme case of Poland, real wages grew faster than productivity, sucking in more imports. In 1976 the government intervened with a highly unpopular food price rise and diversion of exportable goods to the domestic market, making the debt problem even less manageable and stimulating radical opposition. ${ }^{41}$

However, for a while the lenders were not seriously concerned. Western states and businesses heavily invested in deepening détente and expanding East-West exchanges. Even though some Western banks and government officials already began to feel concerned in 1977, the overall assumption was that the socialist states (and ultimately the USSR) could guarantee repayment. Maintaining a high (and possibly growing) level of East-West trade remained a paramount goal for both political and commercial reasons. ${ }^{42}$

Therefore, credits were extended and renewed until the moment of reckoning, which came in 1979 when the US Federal Reserve reacted to growing inflation and a new oil price rise with a restrictive monetary policy. The sharp increases in the cost of energy and interest rates radically altered the international financial landscape. Debt servicing became far more expensive, and the ensuing recession further reduced the debtors' ability to export. Highly indebted countries - both in Eastern Europe and Latin America - entered an era of severe economic hardship. ${ }^{43}$

The already apparent flaws in the socialists' strategies based on Western imports and credits became serious vulnerabilities, as the very interconnectedness with world markets that they had pursued (as a path to prosperity and stabilisation) now turned into a suffocating constraint. The debts grew more expensive. Oil and many raw material prices rose. Exports declined as a result of the global recessionary trend and collapsed towards "third world" countries whose own debt burden was fast becoming untenable. ${ }^{44}$

With a debt trap looming large (see Appendix, Table A.5), the classical response would have been domestic deflation to cut imports and eventually restore equilibrium. However, this went against the grain of the strategy pursued thus far and belied the rhetoric of prosperous modernising socialism. Above all, it carried considerable dangers. When in July 1980 the Polish government announced hefty food-price increases, workers' strikes swept the country with such strength that they forced the recognition of an independent trade union, Solidarnosc, which soon became the backbone of a massive opposition movement. ${ }^{45}$ With Poland entering a profound crisis that threatened the regime's survival (and depressed exports even further), policies decreasing consumption appeared too dangerous across the socialist bloc. Instead, import reduction was primarily pursued with cuts in investment, a stopgap measure that further reduced growth and export capacity. 
As a result, the debt crisis rapidly intensified. In 1981, Poland negotiated rescheduling agreements but its financial position deteriorated even further after the imposition of martial law, which brought US sanctions and a tightening of Western credit. In rapid succession, all the indebted countries of the socialist bloc and Yugoslavia had to adopt emergency measures. Hungary decided to stabilise its finances by applying to the International Monetary Fund, and it was admitted in 1982 (Poland also applied, but its entry, which only took place in 1986, was made conditional on ending martial law). The GDR turned to West Germany, whose massive credit allowed it to restructure its debt in 1983. Romania prioritised repayment of foreign debt and so imposed draconian domestic austerity. ${ }^{46}$

Within a few years external liabilities were lessened, but the socialist economies suffered badly with reduced capacity, anaemic growth, lower levels of income and consumption, and an even larger productivity gap vis-à-vis the West. East-West exchanges were reduced, but there was no going back to semi-autarky. Despite substantial national variations, dependence on Western finance and technology had become ingrained. The West itself did not cut economic ties in the years of renewed bipolar tensions that followed the Soviet invasion of Afghanistan and martial law in Poland. The US adopted a punitive strategy of sanctions and a trade embargo, but Western Europe resisted this approach and strove (rather successfully) to preserve the key elements of European détente. As Helmut Schmidt stated at the Venice G-7 summit in 1980, economic exchanges were not simply 'a mere matter of trade' but 'a moral and historical necessity to reach a better understanding with the East, and especially Poland' ${ }^{47}$ Thus crucial East-West commercial and financial links were maintained throughout the 1980s, the US hard-line strategy proved ineffective and was eventually forsaken, and Western European financial clout came increasingly to be used to negotiate political goals too (like the mellowing and ending of martial law in Poland or support for reforms in Hungary). ${ }^{48}$

However, the 1970s import-based socialist strategies were in tatters, and the sharp contrast between failed promises and renewed hardship undermined the regimes' residual domestic authority, credibility and solidity. By the mid-1980s, Western capitalism was triumphantly redefining itself in neo-liberal terms and China was embracing a capitalist economy. The future of socialism in a rapidly globalising world economy appeared unfathomable. Even the socialist elite seemed to have lost confidence and any vision for the future. When the 1989 revolutions brought down their regimes, the leaders and technocrats were confusedly exploring ways to transition to a market economy.

\section{Conclusion}

The import-led socialist strategies of engagement with the market economies were inaugurated under seemingly favourable conditions in the early 1970s. Détente and Ostpolitik offered a reassuring enticing context. With the Keynesian framework still prevalent, the mixed economies of the West appeared steeped in capital controls and regulated trade that channelled or contained market dynamics. The 
notion of East-West convergence might have been far-fetched, but the expectations of mutual advantages deriving from state-regulated exchanges were not.

Some of these conditions, though, started to shift by the middle of the decade, with large capital movements nurturing a more competitive environment of increasingly global scope. The spread of post-Fordist practices, based on more flexible technologies and procedures, amplified the relevance of market dynamics and the consumerist ethos, moving the goalposts towards a harsher all-encompassing market environment. This magnified the 'structural dilemma' of the socialist economies, which 'required more imports and thus more borrowing' but 'were not able to sell their products on the Western markets to a sufficient degree'. ${ }^{49}$ Some of them soon became hostage to a deepening debt trap. However, the different case of Czechoslovakia - which followed a more cautious path of financial prudence and limited exposure to the global economy - shows that their comparative disadvantage ran very deep, and their impediments were rooted in the structure of planned economies. ${ }^{50}$ Where reforms were introduced to adapt to the new demands emanating from the harsh confrontation with capitalist markets, they proved ineffectual or insufficient and fostered a 'relatively slow ... disintegration of the planning regime'. ${ }^{51}$

Thus strategies meant to harness market mechanisms to the prosperity and stability of socialist regimes brought unintended - and largely opposite - consequences. Rather than a more confident socialism on an upward trajectory of modernisation, the heightened confrontation with globalising markets delivered uneven, deteriorating and ultimately unsustainable economic performances. Dependence on the West grew deeper in material terms and inescapable in its symbolic meanings. Not only was the world not going the socialist way, but socialism grew increasingly mired in the uncomfortable role (and image) of a subaltern system whose degree of autonomy and self-determination was rapidly dwindling..$^{52}$ The bloc itself grew more dissimilar and fractious as trade intensification with the West exasperated divergencies among national paths and policy options, fostered a search for separate deals and solutions, and made the bloc's cohesion not only more difficult to manage - as Moscow could not take on the burden of its allies' debt - but also less valuable as a shared resource. ${ }^{53}$

The 1970s promise of increasing welfare and consumption might have stabilised the regimes in the short term, but it also shifted the ground of their domestic legitimisation towards capitalist values of individualised consumption in the private sphere. It was a metric that socialism could not successfully sustain since it was outcompeted in terms of productivity, quality and variety, and that fostered processes of identification with Western notions of personal freedom and wellbeing. ${ }^{54}$ Intertwined with the emerging politics of human rights and the financial dependence on Western credit, the rise in consumerist expectations brought the West deep within. The possibilities for the regimes to shield their societies from their adversary's influence and allure were ever more limited. ${ }^{55}$

Therefore, interpretations of 1989 centred on security and geopolitical factors, and particularly on Gorbachev's withdrawal of the Soviet guarantee to the socialist regimes of central-eastern Europe,${ }^{56}$ need to be qualified and contextualised. 
Gorbachev's choices were obviously crucial in dispelling notions (already quite fanciful at that point) that help for the regimes could come from Moscow. However, these interpretations do not account for too many key factors: the regimes' long forsaken economic dynamism; their all too manifest failure in the sociocultural competition with the West; the long-term unravelling of their viability and coherence; their citizenry's deep and widespread alienation, well beyond the perimeter of structured opposition; and the vanishing of any confidence that socialism had a promising future. Without these factors, one cannot explain the 'elites' sense of exhaustion with their own project', ${ }^{57}$ the crucial loss of will and confidence that eventually gripped officialdom all the way up. This was the most decisive feature in 1989.

Two decades of deepening East-West interaction, with increasing exposure to the material pressures and socio-cultural influences of market globalisation, had made the regimes more brittle and ineffective. They had exposed their structural weaknesses, magnified their inbuilt dependencies, blown their residual rationale and, ultimately, emptied socialism out. The extended processes that this book explores and compares in their national settings were key determinants of the protracted demise and then sudden collapse of socialism. At the same time, they set some of the foundations on which the transition would take place, with legacies of trans-nationalisation that would mould the new democratic republics' paths to their turn-of-the-century Europeanisation and globalisation. ${ }^{58}$

\section{Notes}

1 Maier, "Thirty years after," 604. An analogous reading is also in Berend, From the Soviet bloc; Romero, Storia della guerra fredda; Pons, The global revolution; Westad, The Cold War.

2 See Frieden, Global capitalism, 351-97.

3 Kotkin, "The kiss of debt," 91. See also Kotkin and Gross, Uncivil society.

4 For a recent scholarly overview of planning cultures and actors which highlights comparability and transnational East-West interaction, see Christian, Kott and Matejka, Planning in Cold War Europe.

5 Rodgers, Age of fracture. On the relevance of market ideas across socialist Europe and their contribution to neo-liberal culture, see Bockman, Markets in the name of socialism.

6 Berend, From the Soviet bloc, 35.

7 Maier, "Thirty years after," 608.

8 See the overview by Harrison, "Communism and Economic Modernization," 388-404, and Kott, "The social engineering project," 195-222.

9 See Sanchez-Sibony, Red globalization; Stone, Satellites and commissars; Bergson, Planning and performance; Marrese and Vaňous, Soviet subsidization of trade.

10 Staniszkis, "Patterns of change in Eastern Europe," 77-97.

11 Kott, "Cold War internationalism," 340-62.

12 Pula, Globalization under and after socialism.

13 See Mark and Rupprecht, "The socialist world in global history," 81-114.

14 Mark and Rupprecht, "The socialist world in global history," 84. On this fundamental unresolved tension, see the discussion by Pons, The Global Revolution.

15 See Lorenzini, Global development; special issue on the "New International Economic Order," in Humanity 6:1 (2015); Hilger, "Communism, de-colonization, and the third world," 317-40. 
16 Smith and Ilic, Khrushchev in the Kremlin); Autio-Sarasmo, "Stagnation or not?," 87-103.

17 Fürst and Bittner, "The aging pioneer," 281-306.

18 Steiner, "The decline of Soviet-type economies," 203-4.

19 Hanson, The rise and fall of the Soviet economy; Feygin, Building a ruin.

20 On reformist Marxism until 1968, see Trencsényi et al., Negotiating modernity.

21 Kolar, "Post-Stalinist reformism," 170. On the retreat from socialist reform thinking by experts and intellectuals after 1968, see Zubok, Zhivago's children, ch. 8.

22 Steiner, "The decline of Soviet-type economies," 206.

23 Godard, "The Council for Mutual Economic Assistance," 287-323; Lorenzini, "The socialist camp," 341-63; Kansikas, Socialist countries face the European Community; Crump, The Warsaw Pact reconsidered; Muehlenbeck and Telepneva, Warsaw Pact intervention.

24 On the multiple, even contrasting goals, dimensions and results of détente, see the specialissue debate on "Détente and Its Legacy," in Cold War History 8:4 (November 2008).

25 Zubok, A failed empire, 209-25; Hanhimäki, The rise and fall of détente; Kieninger, Dynamic détente.

26 Loth and Soutou, The making of détente; Sarotte, Dealing with the devil.

27 Archiwum Akt Nowyth (AAN - Central Archives of Modern Records), KC PZPR 1354, v/120, "Węzłowe kierunki i zadania politiki zagranicznej PRL w 1974" (Ministry of Foreign Affairs guidelines for 1974), 15 January 1974, 3, quoted in Chapter 4 by Aleksandra Komornicka in this book.

28 See "Response to NSSM 163 Prepared by the Ad Hoc Group on Economic Policies Toward Eastern Europe," Washington, 1 February 1973, in Miller, Selvage and Van Hook, FRUS, Document 26.

29 Bange and Villaume, The long détente; Kieninger, The diplomacy of détente; Villaume and Westad, Perforating the Iron Curtain.

30 Romano, Détente in Europe to European détente; Ludlow, Ostpolitik-Westpolitik, 1965-1973.

31 Villaume, Mariager and Porsdam, The 'long 1970s'; Snyder, Human rights activism; Blumenau, Hanhimäki and Zanchetta, Unexpected transformations?

32 Jarzabek, "Polish reactions to the West German Ostpolitik," 35-55, and Bange, "The GDR in the era of détente," 57-77.

33 Möckli, European foreign policy; Schulz and Schwartz, The strained alliance; Gfeller, Building a European identity.

34 Garavini, After empires; Bini, Garavini and Romero, Oil shock; Dietrich, Oil revolution.

35 Mourlon-Druol and Romero, International summitry and global governance; Sargent, A superpower transformed.

36 Chassaigne, Les Années 1970; Ferguson et al., The Shock of the Global.

37 Pula, Globalization under and after socialism, 23.

38 See Table A.1 in the Appendix and Zloch-Christy, Debt problems of Eastern Europe, $31-4$.

39 See the chapters in this book about Bulgaria, Romania, Yugoslavia and even Czechoslovakia.

40 Steiner, The plans that failed, 141-93.

41 Poznański, Poland's protracted transition and Chapter 4 by Aleksandra Komornicka in this book.

42 See, for instance, The UK National Archives (TNA), CAB133/467, "Economic Summit Meeting 27-28 June 1976: Steering Brief by FCO," 23 June 1976; Historical Archives of the European Union (HAEU), EN 1569, "Relations between the Community and eastern Europe, 1 April 1977"; Romano, "G-7s, European Councils and East-West Economic Relations," 198-222.

43 Axilrod, Inside the Fed; Frieden, Global capitalism, 372-400.

44 Trecker, "Circle of debt." 
45 Paczkowski and Byrne, From Solidarity to martial law.

46 Graf, "Before Strauß”; Köves, The CMEA countries.

47 TNA, PREM19/189, "Second Session of Economic Summit on 22 June 1980 at 1515 hours: discussion of political matters." See also TNA, PREM19/188, Michael Palliser to M. Alexander, "Political Discussion at the Venice Summit," 6 June 1980.

48 See Esno, "Reagan's economic war," 281-304; Bátonyi, "“Creative ferment in Eastern Europe," 638-66; Bartel, "The power of omission," 200-20.

49 Steiner, "The Decline of Soviet-Type Economies," 214.

50 See Chapter 6 by Pavel Szobi in this book.

51 Poznański, Poland's protracted transition, xi.

52 See the discussion in Mark and Rupprecht, "Europe's '1989' in global context," 224-49.

53 Godard and Crump, "Reassessing communist international organisations," 85-109; Lüthi, "Drifting apart."

54 Bartha, "Welfare dictatorships," 63-82; Péteri, Imagining the West in Eastern Europe; Lovell, "Communist propaganda and media," 354-75.

55 Badalassi and Snyder, The CSCE and the end of the Cold War.

56 Kramer, "The demise of the Soviet Bloc," 7-62; Zubok, "The collapse of the Soviet Union," 250-77.

57 Mark et al., 1989: a global history of Eastern Europe, 43.

58 See Ther, Europe since 1989; Jarausch, Out of ashes.

\section{Bibliography}

\section{Published primary sources}

James E. Miller, Douglas E. Selvage, Laurie Van Hook, eds. Foreign Relations of the United States (FRUS) 1969-1976, Volume XXIX, Eastern Europe; Eastern Mediterranean, 19691972. Washington, DC: United States Government Printing Office, 2005.

\section{Secondary sources}

Autio-Sarasmo, Sari. "Stagnation or not? The Brezhnev leadership and East-West interaction." In Reconsidering stagnation in the Brezhnev Era: ideology and exchange, edited by Dina Fainberg and Artemy M. Kalinovsky, 87-103. Lanham: Lexington Books, 2016.

Axilrod, Stephen. Inside the Fed: monetary policy and its management, Martin through Greenspan to Bernanke. Cambridge, MA: MIT Press, 2009.

Badalassi, Nicolas and Sarah B. Snyder, eds. The CSCE and the end of the Cold War: diplomacy, societies and human rights, 1972-1990. New York: Berghahn Books, 2019.

Bange, Oliver. "The GDR in the era of détente." In Perforating the Iron Curtain: European détente, transatlantic relations, and the Cold War, 1965-1985, edited by Poul Villaume and Odd Arne Westad, 57-77. Copenhagen: Museum Tusculanum, 2010.

Bange, Oliver and Poul Villaume, eds. The long détente: changing concepts of security and cooperation in Europe, 1950s-1980s. Budapest: Central European University Press, 2017.

Bartel, Fritz. "The power of omission. The IMF and the democratic transitions in Poland and Hungary." In New perspectives on the end of the Cold War: unexpected transformations?, edited by Bernhard Blumenau, Jussi M. Hanhimäki and Barbara Zanchetta, 200-20. London: Routledge, 2018.

Bartha, Eszter. "Welfare dictatorships, the working class and the change of regimes in East Germany and Hungary." In Reflections on 1989 in Eastern Europe, edited by Terry Cox, 63-82. London: Routledge, 2013. 
Bátonyi, Gábor. “'Creative ferment in Eastern Europe': Thatcher's diplomacy and the transformation of Hungary in the mid-1980s." Diplomacy \& Statecraft 29:4 (2018): 638-66.

Berend, Iván T. From the Soviet bloc to the European Union: the economic and social transformation of Central and Eastern Europe since 1973. New York: Cambridge University Press, 2009.

Bergson, Abram. Planning and performance in socialist economies: the USSR and Eastern Europe. Boston: Unwin Hyman, 1989.

Bini, Elisabetta, Giuliano Garavini and Federico Romero, eds. Oil shock: the 1973 crisis and its economic legacy. London: I.B. Tauris, 2016.

Blumenau, Bernhard, Jussi M. Hanhimäki and Barbara Zanchetta, eds. New perspectives on the end of the Cold War: unexpected transformations? New York: Routledge, 2018.

Bockman, Johanna. Markets in the name of socialism: the left-wing origins of neoliberalism. Stanford: Stanford University Press, 2011.

Chassaigne, Philippe. Les Années 1970: fin d'un monde et origine de notre modernité. Paris: Armand Colin, 2008.

Christian, Michel, Sandrine Kott and Ondreij Matejka, eds. Planning in Cold War Europe: competition, cooperation, circulation (1950s-1970s). Berlin: De Gruyter, 2018.

Cox, Terry, ed. Reflections on 1989 in Eastern Europe. London: Routledge, 2013.

Crump, Laurien. The Warsaw Pact reconsidered: international relations in Eastern Europe, 1955-1969. London: Routledge, 2015.

Dietrich, Christopher. Oil revolution: anticolonial elites, sovereign rights, and the economic culture of decolonization. Cambridge: Cambridge University Press, 2017.

Esno, Tyler. "Reagan's economic war on the Soviet Union." Diplomatic History 42:2 (April 2018): 281-304.

Feygin, Yakov. Building a ruin: the international politics of Soviet economic reform 19561992. Cambridge, MA: Harvard University Press, forthcoming.

Frieden, Jeffry A. Global capitalism: its fall and rise in the twentieth century. New York: W.W. Norton, 2006.

Fürst, Juliane and Stephen V. Bittner. "The aging pioneer: late Soviet socialist society, its challenges and challengers." In The Cambridge history of communism, vol. 3, Endgames? Late communism in global perspective, 1968 to the present, edited by Juliane Fürst, Silvio Pons and Mark Selden, 281-306. Cambridge: Cambridge University Press, 2017.

Fürst, Juliane, Silvio Pons, Mark Selden, eds. The Cambridge history of communism, vol. 3, Endgames? Late communism in global perspective, 1968 to the present. Cambridge: Cambridge University Press, 2017.

Garavini, Giuliano. After empires: European integration, decolonization, and the challenge from the global South, 1957-1985. Oxford: Oxford University Press, 2012.

Gfeller, Aurélie Elisa. Building a European identity: France, the United States, and the oil shock, 1973-1974. New York: Berghahn Books, 2012.

Godard, Simon. "The Council for Mutual Economic Assistance and the failed coordination of planning in the socialist bloc in the 1960s." In Planning in Cold War Europe: competition, cooperation, circulation (1950s-1970s), edited by Michel Christian, Sandrine Kott and Ondreij Matejka, 287-323. Berlin: De Gruyter, 2018.

Godard, Simon and Laurien Crump. "Reassessing communist international organisations: a comparative analysis of COMECON and the Warsaw Pact in relation to their Western competitors." Contemporary European History 27:1 (2018): 85-109.

Graf, Maximilian. "Before Strauß: the East German struggle to avoid bankruptcy during the debt crisis revisited." International History Review (2019): 1-18. Accessed 12 March 2020. https://doi.org/10.1080/07075332.2019.1641542. 
Hanhimäki, Jussi M. The rise and fall of détente: American foreign policy and the transformation of the Cold War. Washington, DC: Potomac Books, 2013.

Hanson, Philip. The rise and fall of the Soviet economy: an economic history of the USSR from 1945. London: Longman, 2003.

Hilger, Andreas. "Communism, de-colonization, and the third world." In The Cambridge history of communism, vol. 2, The socialist camp and world power 1941-1960s, edited by Norman Naimark, Silvio Pons and Sophie Quinn-Judge, 317-40. Cambridge: Cambridge University Press, 2017.

Jarausch, Konrad Hugo. Out of ashes: a new history of Europe in the twentieth century. Princeton: Princeton University Press, 2015.

Jarzabek, Wanda. "Polish reactions to the West German Ostpolitik and East-West detente, 1966-78." In Perforating the Iron Curtain: European détente, transatlantic relations, and the Cold War, 1965-1985, edited by Poul Villaume and Odd Arne Westad, 35-55. Copenhagen: Museum Tusculanum Press, 2010.

Kansikas, Suvi. Socialist countries face the European Community: Soviet-bloc controversies over East-West trade. Frankfurt: Peter Lang, 2014.

Kieninger, Stephan. Dynamic détente: the United States and Europe, 1964-1975. Lanham: Lexington Books, 2016.

Kieninger, Stephan. The diplomacy of détente: cooperative security policies from Helmut Schmidt to George Shultz. London: Routledge, 2018.

Kolar, Pavel. "Post-Stalinist reformism and the Prague Spring." In The Cambridge history of communism, vol. 2, The socialist camp and world power 1941-1960s, edited by Norman Naimark, Silvio Pons and Sophie Quinn-Judge, 170-95. Cambridge: Cambridge University Press, 2017.

Kotkin, Stephen. "The kiss of debt." In The shock of the global: the 1970s in perspective, edited by Niall Ferguson, Charles S. Maier, Erez Manela and Daniel Sargent, 80-92. Cambridge, MA: Belknap Press of Harvard University Press, 2010.

Kotkin, Stephen and Jan Tomasz Gross. Uncivil society: 1989 and the implosion of the communist establishment. New York: Modern Library, 2009.

Kott, Sandrine. "Cold War internationalism." In Internationalisms: a twentieth-century history, edited by Glenda Sluga and Patricia Clavin, 340-62. Cambridge: Cambridge University Press, 2017.

Kott, Sandrine. "The social engineering project. Exportation of capitalist management culture to Eastern Europe (1950-1980)." In Planning in Cold War Europe: competition, cooperation, circulation (1950s-1970s), edited by Michel Christian, Sandrine Kott and Ondreij Matejka, 192-222. Berlin: De Gruyter, 2018.

Köves, András. The CMEA countries in the world economy: turning inwards or turning outwards. Budapest: Akadémiai Kiadó, 1985.

Kramer, Mark. "The demise of the Soviet bloc." In Reflections on 1989 in Eastern Europe, edited by Terry Cox, 7-62. London: Routledge, 2013.

Lorenzini, Sara. "The socialist camp and the challenge of economic modernization in the third world." In The Cambridge history of communism, vol. 2, The socialist camp and world power 1941-1960s, edited by Norman Naimark, Silvio Pons and Sophie QuinnJudge, 341-63. Cambridge: Cambridge University Press, 2017.

Lorenzini, Sara. Global development: a Cold War history. Princeton: Princeton University Press, 2019.

Loth, Wilfried and Georges-Henri Soutou, eds. The making of détente: Eastern and Western Europe in the Cold War, 1965-75. London: Routledge, 2008.

Lovell, Stephen. "Communist propaganda and media in the era of the Cold War." In The Cambridge history of communism, vol. 3, Endgames? Late communism in global 
perspective, 1968 to the present, edited Juliane Fürst, Silvio Pons, Mark Selden, 354-75. Cambridge: Cambridge University Press, 2017.

Ludlow, Piers N., ed. European integration and the Cold War: Ostpolitik-Westpolitik, 1965-1973. London: Routledge, 2007.

Lüthi, Lorenz M. "Drifting apart: Soviet energy and the cohesion of the communist bloc in the 1970s and 1980s." In Cold War energy: a transnational history of Soviet oil and gas, edited by Jeronim Perović, 371-400. Basingstoke: Palgrave Macmillan, 2017.

Maier, Charles S. "Thirty years after: the end of European communism in historical perspective." In The Cambridge history of communism, vol. 3, Endgames? Late communism in global perspective, 1968 to the present edited by Juliane Fürst, Silvio Pons, Mark Selden, 600-21. Cambridge: Cambridge University Press, 2017.

Mark, James, Bogdan Jacob, Tobias Rupprecht and Ljubica Spaskovska. 1989: a global history of Eastern Europe. Cambridge: Cambridge University Press, 2019.

Mark, James and Tobias Rupprecht. "Europe's '1989' in global context." In The Cambridge history of communism, vol. 3, Endgames? Late communism in global perspective, 1968 to the present, edited by Juliane Fürst, Silvio Pons, Mark Selden, 224-49. Cambridge: Cambridge University Press, 2017.

Mark, James and Tobias Rupprecht. "The socialist world in global history. From absentee to victim to co-producer." In The practice of global history: European perspectives, edited by Matthias Middell, 81-113. London: Bloomsbury, 2019.

Marrese, Michael and Jan Vaňous. Soviet subsidization of trade with Eastern Europe: a Soviet perspective. Berkeley: University of California, 1983.

Möckli, Daniel. European foreign policy during the Cold War. London: Tauris, 2009.

Mourlon-Druol, Emmanueland Federico Romero, eds. International summitry and global governance: the rise of the G7 and the European Council, 1974-1991. London: Taylor \& Francis, 2014.

Muehlenbeck Philip E. and Natalia Telepneva, eds. Warsaw Pact intervention in the third world: aid and influence in the Cold War. London: I.B. Tauris, 2018.

Naimark, Norman, Silvio Pons and Sophie Quinn-Judge, eds. The Cambridge history of communism, vol. 2. The socialist camp and world power 1941-1960s. Cambridge: Cambridge University Press, 2017.

Paczkowski, Andrzej and Malcolm Byrne. From Solidarity to martial law: the Polish Crisis of 1980-1981. Budapest: Central European University Press, 2007.

Péteri, György, ed. Imagining the West in Eastern Europe and the Soviet Union. Pittsburgh: University of Pittsburgh Press, 2010.

Pons, Silvio. The global revolution: a history of international communism 1917-1991. Oxford: Oxford University Press, 2014.

Poznański, Kazimierz. Poland's protracted transition: institutional change and economic growth 1970-1994. Cambridge: Cambridge University Press, 1996.

Pula, Besnik. Globalization under and after socialism: the evolution of transnational capital in Central and Eastern Europe. Stanford: Stanford University Press, 2018.

Rodgers, Daniel. Age of fracture. Cambridge, MA: Belknap Press of Harvard University Press, 2011.

Romano, Angela. From détente in Europe to European détente: how the West shaped the Helsinki CSCE. Bruxelles: Lang, 2009.

Romano, Angela. "G-7s, European Councils and East-West economic relations, 19751982." In International summitry and global governance: the rise of the $G 7$ and the European Council, 1974-1991, edited by Emmanuel Mourlon-Druol and Federico Romero, 198-222. London: Taylor \& Francis, 2014.

Romero, Federico. Storia della guerra fredda. Torino: Einaudi, 2009. 
Sanchez-Sibony, Oscar. Red globalization: the political economy of the Soviet Cold War from Stalin to Khrushchev. New York: Cambridge University Press, 2014.

Sargent, Daniel J. A superpower transformed: the remaking of American foreign relations in the 1970s. Oxford: Oxford University Press, 2015.

Sarotte, Mary E. Dealing with the devil: East Germany, détente, and Ostpolitik, 19691973. Chapel Hill: University of North Carolina Press, 2001.

Schulz, Matthias and Thomas Alan Schwartz, eds. The strained alliance: US-European relations from Nixon to Carter. New York: Cambridge University Press, 2009.

Smith, Jeremy and Melanie Ilic, eds. Khrushchev in the Kremlin: policy and government in the Soviet Union, 1953-1964. London: Routledge, 2011.

Smith, Stephen A., ed. The Oxford handbook of the history of communism. Oxford: Oxford University Press, 2014.

Snyder, Sarah B. Human rights activism and the end of the Cold War: a transnational history of the Helsinki Network. New York: Cambridge University Press, 2011.

Staniszkis, Jadwiga. "Patterns of change in Eastern Europe." East European Politics and Society 4:1 (1989): 77-97.

Steiner, André. The plans that failed: an economic history of the GDR. New York: Berghahn Books, 2010.

Steiner, André. "The decline of Soviet-type economies." In The Cambridge history of communism, vol. 3, Endgames? Late communism in global perspective, 1968 to the Present, edited by Juliane Fürst, Silvio Pons and Mark Selden, 203-23. Cambridge: Cambridge University Press, 2017.

Stone, Randall. Satellites and commissars: strategy and conflict in the politics of Sovietbloc trade. Princeton: Princeton University Press, 1996.

Ther, Philipp. Europe since 1989: a history. Princeton: Princeton University Press, 2016.

Trecker, Max. "Circle of debt: how the crisis of the global South in the 1980s affected the socialist East." Cold War History 20:1 (2020): 1-19.

Trencsényi, Balázs, Michal Kopeček, Luka Lisjak Gabrijelčič, Maria Falina, Mónika Baár and Maciej Janowski. A history of modern political thought in East Central Europe. Volume II: negotiating modernity in the 'short twentieth century' and beyond, part I: 1918 1968. Oxford: Oxford Scholarship Online, 2018. Accessed 12 March 2020. https://doi. org/10.1093/oso/9780198737155.001.0001.

Villaume, Poul, Rasmus Mariager and Helle Porsdam, eds. The 'long 1970s': human rights, East-West détente and transnational relations. London: Routledge, 2016.

Villaume, Poul and Odd Arne Westad, eds. Perforating the Iron Curtain: European détente, transatlantic relations, and the Cold War, 1965-1985. Copenhagen: Museum Tusculanum Press, 2010.

Westad, Odd Arne. The Cold War: a world history. New York: Basic Books, 2017.

Zloch-Christy, Iliana. Debt problems of Eastern Europe. Cambridge: Cambridge University Press, 1987.

Zubok, Vladislav. A failed empire: the Soviet Union in the Cold War from Stalin to Gorbachev. Chapel Hill: University of North Carolina Press, 2007.

Zubok, Vladislav. Zhivago's children: the last Russian intelligentsia. Cambridge, MA: Belknap Press of Harvard University Press, 2009.

Zubok, Vladislav. "The collapse of the Soviet Union." In The Cambridge history of communism, vol. 3, Endgames? Late communism in global perspective, 1968 to the present, edited by Juliane Fürst, Silvio Pons and Mark Selden, 250-77. Cambridge: Cambridge University Press, 2017. 